\title{
Strain differences in basal metabolism of behaviorally defined rats
}

\author{
GORDON M. HARRINGTON and LOUIS R. HELLWIG \\ University of Northern Iowa, Cedar Falls, Iowa 50613
}

\begin{abstract}
Oxygen basal metabolism using a closed-circuit chamber system was obtained for 549 rats from 12 inbred strains: ACI, A990, A35322, F344, INR, IR, MNR/Har, MNRA, MR/Har, TS1, TS3, WAG. The results provide parametric data for methodological use and add to the standardization of these strains as behaviorally defined lines.
\end{abstract}

The possibility of association of basal metabolism with behavioral variables was first explored almost half a century ago in a study of spontaneous activity by Rundquist and Bellis (1933). In the same year, differences in basal metabolic rate were also investigated for rats differing in maze-learning performance (Heron, 1933; Heron \& Yugend, 1936). An attempt was made to link these two behavioral phenomena both with each other and with metabolism (Rundquist \& Heron, 1935), but the connections remain obscure. Little subsequent attention seems to have been paid to basal metabolism in behavioral studies.

In an unpublished 1961 study using an operant conditioning procedure to test for differences in groups that had been differentiated on perceptual variables, one of us (G.M.H.) obtained results so strongly confirmatory of the experimental hypothesis as to be suspicious. In searching for all possible alternative explanations, it was discovered that basal metabolic rate of the subjects was highly correlated with leverpress operant acquisition rate and with asymptotic response rate with continuous reinforcement. To gain experimental control over this unexpected variable, a search was undertaken to find lines of rats differing in basal metabolic rate. This search revealed a paucity of standardization data on rats necessary for informed selection of those lines most appropriate for a given experimental problem. The present study was undertaken to provide standardization data on basal metabolism for those 12 genetically defined lines of rats having the highest citation frequency in the behavioral literature. It led in turn to a number of parametric studies (Harrington, 1971a, 1971b, 1972, 1979a, 1979b, 1979c, 1979d, 1979e, 1979f, 1979g, 1979h, 1979i; Harrington \& Hellwig, 1979), contributing to such behavioral standardization and paralleling the methodological advances in precise specification of animal models in biomedical research (International Committee on Laboratory Animals, 1971).

\section{METHOD}

\section{Subjects}

Subjects were 549 rats, aged 115-129 days, with a minimum of 20 animals of each sex within each of the following 12 inbred strains: ACI/Har, A990/Har, A35322/Har, F344/DuHar, INR, IR, MNR/Har, MNRA (formerly MNR-a/Har), MR/Har, TS1, TS3, WAG/Har. All lines are designated by the standard nomenclature for this species and are described in the fourth international listing (Festing \& Staats, 1973). Animals were bred and maintained at $25.5^{\circ} \mathrm{C} \pm 1.1^{\circ} \mathrm{C}$ and $40 \% \pm 5 \%$ relative humidity. Breeders and pups were housed under natural light cycle. Pups were handled for $1 \mathrm{~min}$ on alternate days from age 14 to 45 days. At 45 days, they were transferred to individual cages with 24-h light cycle. More detailed descriptions are available elsewhere (Harrington, 1968).

\section{Apparatus and Procedure}

Animals were put under 24-h food deprivation. Then, they were briefly handled and, when calm, individually placed into a large desiccator. A petri dish containing Drierite was placed under the desiccator plate to absorb exhaled water vapor. Petroleum jelly was placed between the bowl and cover to prevent air leakage. With the use of tubing and a syringe filled with air, consumed oxygen was replaced. The amount of inserted air necessary to maintain normal air pressure inside the chamber was recorded every $15 \mathrm{~min}$ for $1 \mathrm{~h}$.

\section{RESULTS AND DISCUSSION}

Since energy consumption is more closely related to body area than to body weight, it is conventional to express metabolic rates in terms of body area. Brody (1964) has discussed quite fully the complexities of doing so. Using one of his formulas (Brody, 1964, p. 451) appropriate for the age of the animals, the data were reexpressed as $\mathrm{kCal} / \mathrm{m}^{2} / \mathrm{h}$. The results are summarized in Table 1.

Keeler and King (1942a, 1942b) reported data based on very small Ns from which they inferred an association between the hood gene and basal metabolism. No such association is to be found in these data.

Richter and Rice (1954) suggested that defecation 
Table 1

Basal Metabolic Rate of 12 Inbred Strains of Rats

\begin{tabular}{lcrrr}
\hline & \multicolumn{3}{c}{ Basal Metabolism $\left(\mathrm{kCal} / \mathrm{m}^{2} / \mathrm{h}\right)$} \\
\cline { 2 - 3 } \multicolumn{1}{c}{ Strain } & \multicolumn{2}{c}{ Males } & & Females \\
\cline { 2 - 3 } \cline { 5 - 6 } Mean & SD & & Mean & SD \\
\hline ACI/Har & 37.4 & 8.2 & 43.9 & 12.5 \\
A990/Har & 32.8 & 6.6 & 40.8 & 9.0 \\
A35322/Har & 32.6 & 9.3 & 42.4 & 10.0 \\
F344/DuHar & 34.6 & 6.1 & 37.1 & 10.4 \\
INR & 40.1 & 10.3 & 41.6 & 8.3 \\
IR & 31.9 & 5.5 & 33.7 & 6.9 \\
MNR/Har & 31.7 & 5.2 & 36.7 & 7.8 \\
MNRA & 37.3 & 8.2 & 45.9 & 12.4 \\
MR/Har & 37.0 & 6.8 & 38.8 & 7.5 \\
TS1 & 34.2 & 9.1 & 39.2 & 10.9 \\
TS3 & 42.3 & 10.1 & 44.8 & 10.4 \\
WAG/Har & 32.7 & 6.0 & 40.0 & 9.4 \\
\hline
\end{tabular}

Note $-N \geqslant 20$ for each sex within each strain.

was inversely related to metabolism. Both measures reflected emotionality differentiating wild and domesticated rats. The higher emotionality of wild rats was assumed to be genetic in origin. However, it was easy to interpret their results as reflecting an emotional response of wild rats to the environmental stress of being caged. It is of some interest, therefore, to note that two of the Maudsley nonreactive lines (Broadhurst, 1960) stand near the opposite extremes in basal metabolism. Since these lines were selected for low elimination as an index of "emotionality," it would appear that the defecation measure taps variables that are completely independent of basal metabolism.

\section{REFERENCES}

Broadhurst, P. L. Experiments in psychogenetics: Application of biometrical genetics to the inheritance of behavior. In $\mathrm{H}$. J. Eysenck (Ed.), Experiments in personality. Vol I. Psychogenetics and psychopharmacology. London: Routledge \& Kegan Paul, 1960.

Brody, S. Bioenergetics and growth. New York: Hafner, 1964.

Festing, M., \& StaAts, J. Standardized nomenclature for inbred strains of rats. Transplantation, 1973, 16, 221-245.

HARRINGTON, G. M. Genetic-environmental interaction in "intelligence." I: Biometric genetic analysis of maze performance of Rattus Norvegicus. Developmental Psychobiology, 1968, 1, 211-218.

HaRrington, G. M. Strain differences among rats initiating exploration of differing environments. Psychonomic Science, 1971, 23, 348-349. (a)
HARrington, G. M. Strain differences in rotating wheel activity of the rat. Psychonomic Science, 1971, 23, 363-364. (b)

HARRINGTON, G.M. Strain differences in open field behavior of the rat. Psychonomic Science, 1972, 27, 51-53.

Harrington, G. M. Strain differences in activity of the rat in a shuttle stabilimeter. Bulletin of the Psychonomic Society, $1979,13,149-150$. (a)

Harrington, G. M. Strain differences in activity of the rat using a home cage stabilimeter. Bulletin of the Psychonomic Society, 1979, 13, 151-152. (b)

Harrington, G. M. Strain differences in free operant leverpress levels in the rat. Bulletin of the Psychonomic Society, 1979, 13, 153-154. (c)

Harrington, G. M. Strain differences in light-contingent barpress behavior of the rat. Bulletin of the Psychonomic Society, 1979, 13, 155-156. (d)

HARrington, G. M. Strain differences in open-field behavior of the rat. II. Bulletin of the Psychonomic Society, 1979, 13, 85-86. (e)

HARRINGton, G. M. Strain differences in passive avoidance conditioning in the rat. Bulletin of the Psychonomic Society, 1979, 13, 157-158. (f)

HARRINGTON, G. M. Strain differences in runway learning in the rat. Bulletin of the Psychonomic Society, 1979, 13, 159-160. (g)

Harrington, G. M. Strain differences in shuttle avoidance conditioning in the rat. Bulletin of the Psychonomic Society, 1979, 13, 161-162. (h)

HARRINGTON, G. M. Strain differences in simple operant barpress acquisition to an auditory stimulus by rats. Bulletin of the Psychonomic Society, 1979, 13, 163-164. (i)

Harrington, G. M., \& Hellwig, L. R. Strain differences in organ weights of behaviorally defined rats. Bulletin of the Psychonomic Society, 1979, 13, 167-169.

HERON, W. T. Basal metabolism and maze learning in the rat. Psychological Bulletin, 1933, 30, 723.

Heron, W. T., \& Yugend, S. Basal metabolism and maze learning in rats. Journal of Genetic Psychology, 1936, 48, 471-474.

International Commitee on Laboratory Animals. Defining the laboratory animal. Washington, D.C: National Academy of Sciences, 1971.

KeELER, C. E., \& KING, H. D. Multiple effects of coat color genes in the Norway rat, with special reference to temperament and domestication. Journal of Comparative Psychology, 1942, 34, 241-250. (a)

KeEleR, C. E., \& King, H. D. The taming effect of coat color genes in the Norway rat. Genetics, 1942, 27, 151. (b)

RICHTER, C. P., \& Rice, K. K. Comparison of the effects produced by fasting on gross activity of wild and domesticated Norway rats. American Journal of Physiology, 1954, 179, 305-308.

Rundquist, E. A., \& Bellis, C. J. Respiratory metabolism of active and inactive rats. American Journal of Physiology, 1933, 106, 670-675.

Rundquist, E. A., \& Heron, W. T. Spontaneous activity and maze learning. Journal of Comparative Psychology, 1935, 19, 297-311.

(Received for publication January 3, 1979.) 